\title{
Penerapan Metode (TS-TS) UnTUK Melihat AkTivitas Siswa PADA PEMBElajaRAN MATEMATIKA
}

\author{
THE APPlication (TS-TS) METHOD to SEE STUDENT ACTIVITIES ON \\ MATHEMATICAL LEARNING
}

\author{
Rani $^{1}$, Choirun Niswah ${ }^{2}$ dan Riza Agustiani ${ }^{3}$ \\ ${ }^{1}$ Universitas Islam Negeri Raden Fatah Palembang \\ Palembang, Sumatera Barat, Indonesia \\ rani.bae87@yahoo.com \\ ${ }^{2}$ Universitas Islam Negeri Raden Fatah Palembang \\ Palembang, Sumatera Barat, Indonesia \\ niswah_c@yahoo.com \\ ${ }^{3}$ Universitas Islam Negeri Raden Fatah Palembang \\ Palembang, Sumatera Barat, Indonesia \\ riza.mathedu@gmail.com
}

\begin{abstract}
Abstrak
Aktivitas belajar diartikan sebagai suatu kegiatan yang dilakukan oleh siswa dalam pelaksanaan proses pembelajaran. Aktivitas siswa sangatlah diperlukan dalam proses pembelajaran. Tujuan penelitian ini adalah untuk melihat melihat aktivitas belajar siswa pada pembelajaran matematika setelah diterapkan metode Two Stay Two Stray (TS-TS) di SMP Negeri 19 Palembang. Untuk mengetahui tujuan penelitian, maka yang digunakan dalam penelitian ini adalah Mixed Methods Research. Hasil penelitian ini diambil dari data observasi aktivitas siswa pada setiap pertemuan, wawancara kepada sampel terpilih, dan dokumentasi, kemudian dapat disimpulkan bahwa: setelah diterapkan metode Two Stay Two Stray (TS-TS) dalam pembelajaran matematika di SMP Negeri 19 Palembang, aktivitas belajar siswa termasuk dalam kategori aktif dengan ratarata 75, dimana 12 orang siswa berada pada kategori sangat aktif, 7 orang siswa berada pada kategori aktif, 8 orang siswa berada pada kategori cukup aktif, 3 orang siswa berada ada kategori kurang aktif, dan 1 orang siswa berada pada kategori sangat kurang aktif.

Kata Kunci: aktivitas belajar, metode Two Stay Two Stray (TS-TS).
\end{abstract}

\begin{abstract}
Learning activity is defined as an activity undertaken by students in the implementation of the learning process. Student activity is very necessary in the learning process. The purpose of this study is to observe the student learning activities in the study of mathematics after applied Two Stay Two Stray (TS-TS) method in SMP Negeri 19 Palembang. This research is a Mixed Methods Research. The data of this study is observational data of student activity at each meeting, interview data of the selected sample, and documentation. From the data analysis, it can be concluded that after applied the Two Stay Two Stray (TS-TS) method in mathematics instructions at SMP Negeri 19 Palembang, student learning activities included in the category of active with an average of 75: 12 very active students, 7 active students, 8 sufficient students, 3 less active students, and 1 very less active student.

Keyword: learning activities, methods Two Stay Two Stray (TS-TS).
\end{abstract}




\section{Pendahuluan}

Menurut Dewi (2014: 1), berhasilnya suatu tujuan pendidikan tergantung pada bagaimanaproses pembelajaran tersebut berlangsung yang meliputi aktivitas siswa, respon siswa, dan hasil belajar yang efektif, begitu juga dengan tujuan pembelajarannya. Dewi juga mengatakan bahwa belajar dan pembelajaran merupakanaktivitas yang melekat secara intern dalam diri manusia. Sejalan dengan yang dikatakan Sardiman (2010: 95) bahwa belajar adalah berbuat, tidak ada belajar kalau tidak berbuat. Berbuat dalam konteks ini adalah beraktivitas dalam proses pembelajaran. Oviyanti (2009: 26) juga mengatakan bahwa proses pembelajaran harus berdasarkan prinsip aktivitas, karena tanpa aktivitas proses belajar mengajar tidak mungkin dapat berjalan dengan baik.

Berdasarkan pengalaman langsung peneliti selama PPL di SMP Negeri 19 Palembang dan observasi langsung yang peneliti lakukan, guru mata pelajaran matematika di SMP Negeri 19 Palembang cenderung masih menggunakan proses pembelajaran yang terpusat pada guru. Dalam proses pembelajaran aktivitas yang tampak hanya sekadar memperhatikan dan menegerjakan tugas yang diberikan guru, sehingga proses pembelajaran tidaklah efektif. Hal ini terbukti dari data hasil observasi peneliti, dimana rata-rata aktivitas yang tampak dilakukan siswa kelas VIII di SMP Negeri 19 Palembang selama proses pembelajaran adalah sebesar 47. Berdasarkan kategori aktivitas belajar siswa rata-rata aktivitas 47 masuk dalam kategori kurang aktif. Maka dapat dikatakan bahwa lebih dari separuh aktivitas siswa kelas VIII di SMP Negeri 19 Palembang belum tampak.

Salah satu metode pembelajaran yang dapat membuat aktivitas siswa lebih hidup dalam proses pembelajaran adalah metode pembelajaran Two Stay Two Stray (TS-TS). Metode Two Stay Two Stray membentuk kelompok kecil dengan ciri khas pembentukan kelompok dilakukan secara heterogen kemudian dua orang siswa bertugas sebagai tamu dan dua orang siswa yang lain sebagai tuan rumah. Menurut Huda (2014: 207) metode TS-TS merupakan pembelajaran kelompok dengan tujuan agar siswa dapat saling bekerja sama, bertanggung jawab, saling membantu menyelesaikan masalah, dan melatih siswa untuk bersosialisasi dengan baik. Metode pembelajaran Two Stay Two Stray (TSTS) berfungsi memberikan kesempatan yang sama kepada setiap siswa dalam kelompok untuk lebih aktif dalam bergerak, melihat, mengemukakan pendapat, bertanya, mengingat apa yang didapat dari hasil diskusi kelompok serta cara mereka bersosialisasi dengan kelompok lainnya.

Agar aktivitas belajar siswa yang tampak baik, siswa harus memahami materi terlebih dahulu. Guna 
mempermudah siswa dalam memahami materi, maka guru sebaiknya menjelaskan terlebih dahulu materi yang akan diajarkan secara umum, mengingat tidak semua siswa mau langsung belajar dan membahas materi yang diberikan bersama teman kelompoknya. Maka dari itu, peneliti terdorong untuk melakukan penelitian dengan judul Penerapan Metode Two Stay Two Stray (TS-TS) untuk Melihat Aktivitas Siswa Pada Pembelajaran Matematika di SMP Negeri 19 Palembang.

\section{Metode}

Jenis yang digunakan dalam penelitian ini adalah Mixed Methods Research, yaitu metode penelitian kombinasi. Peneliti menggunakan metode penelitian dengan modelConcurrent Embedded (kombinasicampuran tidak berimbang). Desain penelitian yang akan digunakan dalam penelitian ini adalah One - Shot Case Study. Populasi penelitian ini adalah siswa kelas 8 semester ganjil SMP Negeri 19 Palembang, sedangkan sampelnya adalah salah satu kelas 8 yang ada di SMP Negeri 19 Palembang. Pengambilan sampel mengggunakan teknik cluster random sampling yaitu memilih satu kelas dari delapan kelas yang sudah terbentuk dan kelas yang terpilih adalah kelas 8.2 yang berjumlah 38 siswa.

Teknik pengumpulan data dalam penelitian ini adalah observasi, wawancara dan dokumentasi. Observasi dilakukan untuk menentukan kategori aktivitas siswa, selanjutnya peneliti mengadakan wawancara. Wawacara ini dilakukan untuk mendukung hasil observasi. Selama proses pembelajaran, peneliti membuat dokumentasi video pembelajaran. Video pembelajaran ini digunakan untuk menguatkan hasil observasi dan wawancara. Sehingga data yang didapat benar-benar valid. Observasi dilakukan pada saat proses pembelajaran berlangsung dengan menggunakan lembar observasi yang dilakukan oleh observer. Selanjutnya untuk wawancara dilakukan oleh peneliti sendiri pada saat proses pembelajaran berlangsung dengan menanyakan tentang kesulitan-kesulitan atau hal positif apa saja yang dialami oleh siswa dalam proses pembelajaran untuk mendukung hasil observasi.

Setelah data diperoleh dari hasil observasi, wawancara dan dokumentasi selanjutnya dilakukan perhitungan untuk menentukan kategori aktivitas siswa dengan menggunakan rumus yang dapat dilihat pada gambar di bawah ini. Selanjutnya untuk hasil wawancara digunakan untuk memperkuat hasil observasi. Setelah semua data terkumpul dilakukan pengecekan keabsahan data dengan menggunakan teknik triangulasi teknik untuk mengecek data kepada sumber yang sama dengan teknik yang berbeda sehingga menghasilkan kesimpulan yang benarbenar valid.

\section{Hasil dan Pembahasan}




\section{A. Hasil Penelitian}

1. Deskripsi Pelaksanaan Penelitian Proses pelaksanaan penelitian ini dilakukan dalam empat kali pertemuan, pertemuan pertama pembagian kelompok, pertemuan kedua sampai pertemuan keempat proses pembelajaran dengan metode Two Stay Two Stray (TS-TS) dan observasi aktivitas siswa oleh observer. Proses pembelajaran terdiri dari dua jam pembelajaran dengan alokasi waktu 2 x 40 menit. Dalam melaksanakan proses pembelajaran, ada beberapa fakta yang peneliti temukan beberapa diantaranya:

a. Ada beberapa kelompok yang terlihat bingung saat diskusi kelompok berlangsung. $\mathrm{Hal}$ ini peneliti ketahui saat mengecek LKS, LKS yang mereka kerjakaan masih kosong. Selanjutnya peneliti menanyakan:

$P \quad:$ kenapa LKSnya belum
diisi?
Siswa : kami bingung bu,
cakmano caro ngisinyo hehe.
$P \quad:$ LKSnya dibaca tidak?
Siswa : sudah bu
$P \quad:$ petunjuknya dibaca
dengan teliti idak?

Siswa : sudah bu, tapi masih bingung
$P \quad: \quad$ jangan bingung, kerjakan LKS sesuai petunjuknya. Seperti soal nomor 1 petujuknya minta digambar, maka gambarkanlah. Nanti tanya ibu lagi jika masih bingung.

Siswa : baik bu.

Dari percakapan peneliti dengan siswa dalam proses pembelajaran peneliti mengetahui bahwa siswa telah membaca LKS namun belum memahami petunjuk dengan benar. Dari percakapan tersebut pula peneliti mengetahui bahwa siswa telah melakukan indikator aktivitas visual yaitu pada deskriptor mengamati masalah yang ada dalam LKS. Masalah lain yang peneliti hadapi adalah ketika peneliti meminta tiap kelompok untuk menjadi tamu dan tuan rumah. Pada saat pelaksanaan TS-TS ini berlangsung, suasana kelas menjadi gaduh karena suara siswa. Setelah suasana kelas menjadi tenang peneliti melajutkan proses pembelajaran kembali. Selanjutnya peneliti menemukan jawaban salah satu kelompok yang berbeda dari kelompok lainnya. 


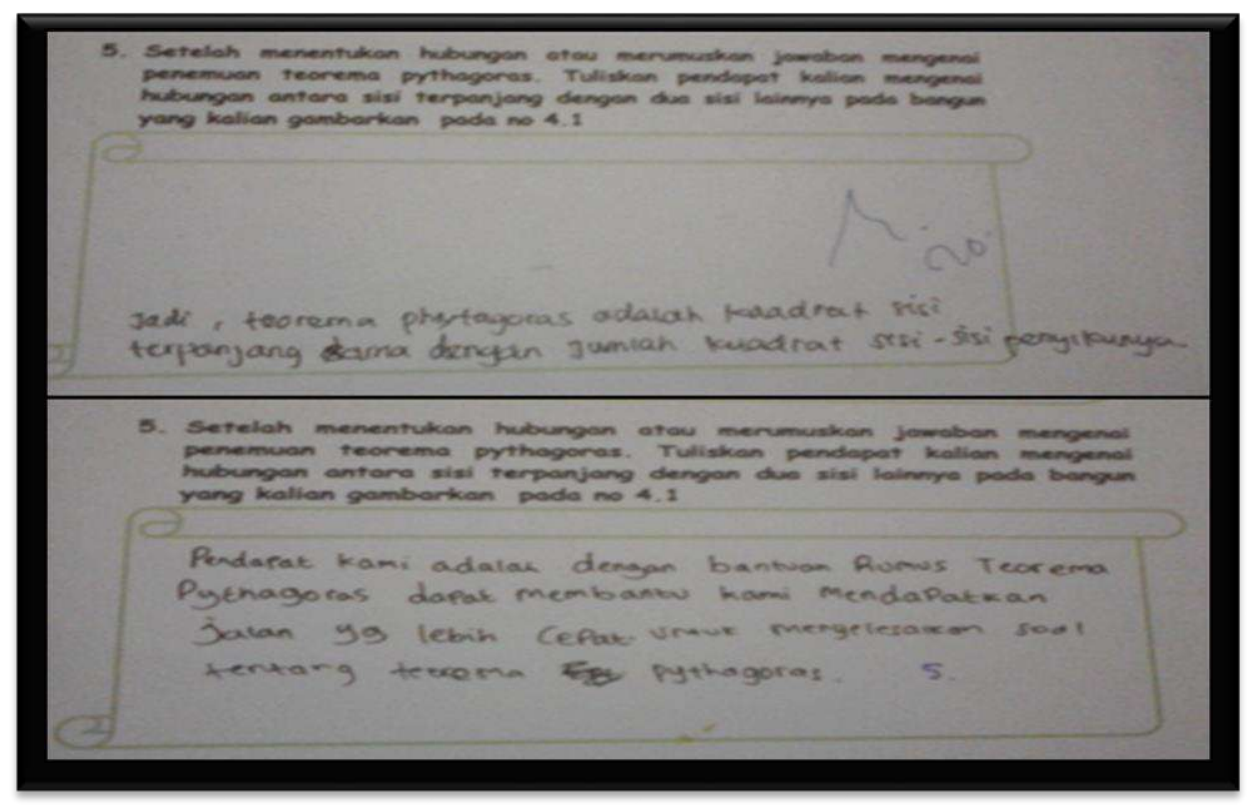

Gambar 1. Hasil Dokumentasi Jawaban LKS Siswa

Dari gambar di atas dapat dilihat bahwa jawaban pada gambar atas adalah jawaban yang tepat dan jawaban pada gambar bawah adalah jawaban yang kurang tepat. Hal ini dikarenakan siswa kurang mampu mengumpulkan informasi yang sesuai dengan hipotesis yang telah dibuat sebelumnya, sehingga siswa kurang memahami apa yang diinginkan oleh soal. Namun, sampai pada tahap ini siswa telah mampu melakukan aktivitas mental dengan baik.

b. Pada saat melakukan pemeriksaan peneliti menghampiri satu demi satu kelompok untuk mengetahui kesulitan apa yang mereka hadapi. Sampailah peneliti pada kelompok terakhir yaitu kelompok 9, peneliti mendapati bahwa kelompok 9 mengalami kesulitan untuk menempelkan bangun segitiga yang telah mereka gambar, kemudian peneliti menanyakan:

$P$ : kenapa ini?

Siswa : ini nah bu, kan gambar setigigo yang kelimo ini sudah kami gambar terus kami gunting tapi pas nak kami tempel bingung bu mano yang siku-sikunyo soalnyo agak beda bentuknyo dengan gambar nomor 1 dan 2.

$P \quad$ : coba mana sisi terpanjang $d n$ sisi terpendek?

Siswa : ini buk yang paling pendek dan ini yang paling panjang, kalau yang bawah idak lebih panjang dari yang ini (sambil menunjukkan gambar)

$P$ : coba kalian tempelkan sudut yang terbentuk oleh sisi terpendek dan sisi bawah pada sudut siku-siku pada gambar di LKS (sambil menunjuk LKS)

Siswa : maksih bu. 
Dari percakapan peneliti dengan siswa dalam proses pembelajaran peneliti mengetahui bahwa siswa mengalami kesulitan ketika akan menempelkan gambar yang sudah mereka buat pada LKS dikarenakan bentuk gambar yang sedikit berbeda meski demikian, mereka sudah mengetahui mana yang disebut sisi terpanjang atau sisi miring. Dari percakapan tersebut pula peneliti mengetahui bahwa siswa telah menggambar bangun segitiga sesuai dengan petunjuk yang ada dalam LKS dimana artinya siswa mampu melakukan indikator aktivitas menggambar.

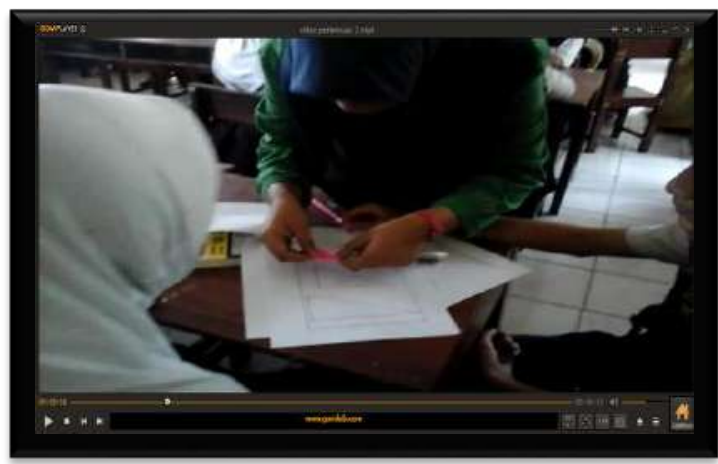

Gambar 2. Hasil Dokumentasi Peneliti Memberikan Solusi Atas Pertanyaan Siswa

Selanjutnya peneliti banyak menemukan kesalahan siswa pada saat menempel gambar. Kebanyakan siswa menempel gambar tidak sesuai pada segitiga yang telah disediakan, sehingga mengakibatkan siswa masih bertanyatanya apakah gambar yang telah ditempel menepati segitiga siku-siku atau tidak.

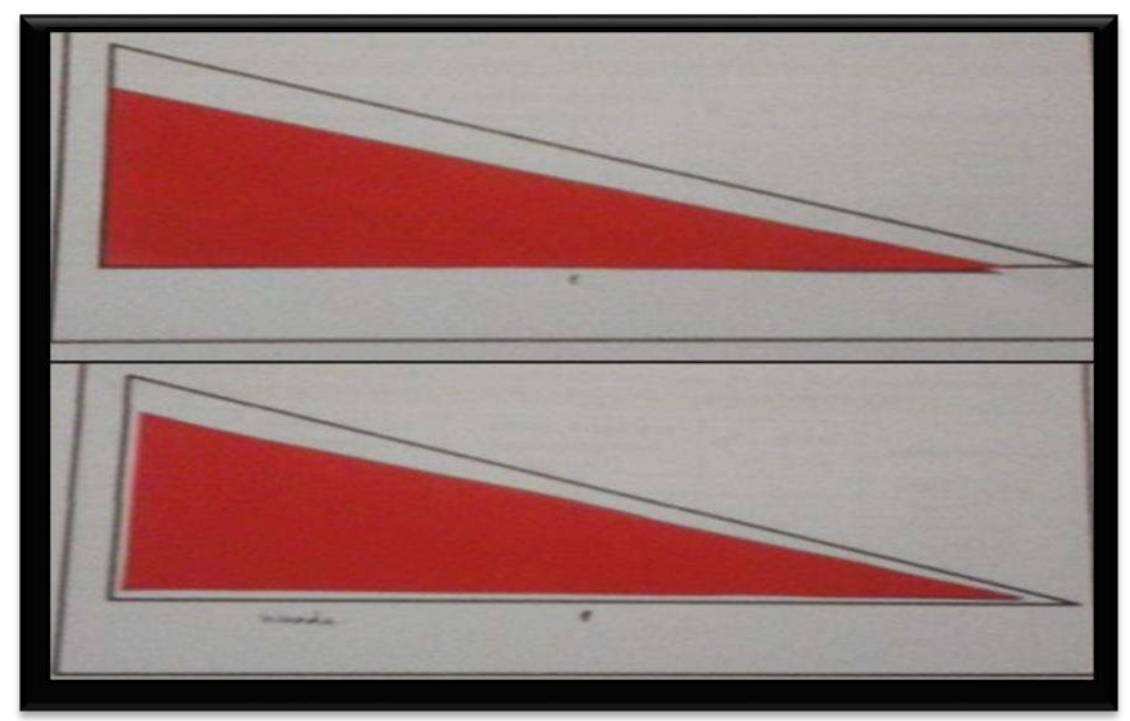

Gambar 3. Hasil Dokumentasi Kesalahan Siswa dalam Menempel Gambar

Meski gambar yang ditempel tidaklah tepat, namun siswa telah mampu melakukan aktivitas menggambar dan aktivitas metrik. Selanjutnya disela-sela peneliti melakukan pemeriksaan kepada tiap-tiap kelompok, salah satu siswa yang berasal dari kelompok 8 menghampiri peneliti kemudian menanyakan: 
Siwa : ibu, membuat hipotesis disini maksudnya bagaimana? Kan ini disuruh isi tabelnya lalu?

$$
\text { P : iya isi tabelnya, }
$$
berdasarkan ukuran segitiga yang kalian buat tadi.

Siswa : oh iyo-iyo paham bu.

$$
P \quad: \quad \text { silahkan kerjakan }
$$

kembali bersama kelompoknya.

Dari percakapan peneliti dengan siswa tersebut peneliti mengetahui bahwa siswa tersebut sebenernya sudah mengetahui dan memahami apa yang akan ia lakukan selanjutnya. Namun siswa tersebut masih kurang yakin dengan apa yang akan ia kerjakan untuk itu ia memastikan kebenaranya dengan bertanya kepada peneliti. Dengan demikian dapat dilihat bahwa siswa tersebut telah mampu melakukan aktivitas visual, aktivitas lisan, aktivitas mendengar, dan aktivitas emosional.

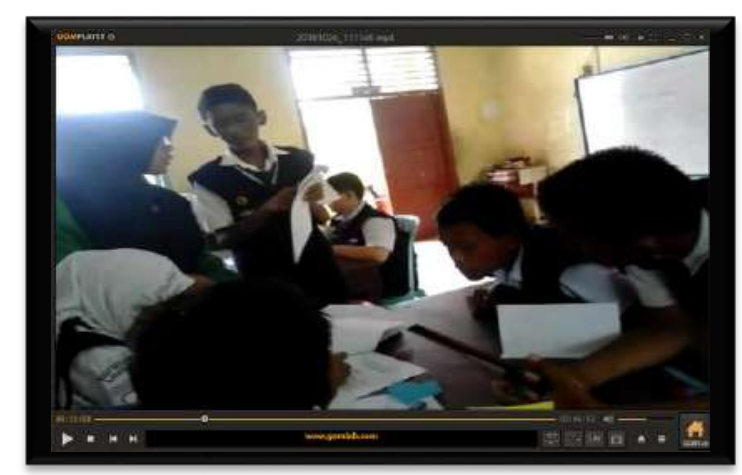

Gambar 4. Hasil Dokumentasi Peneliti Menjelaskan Pertanyaan Siswa

Dari gambar di atas nampak peneliti sedang menjelaskan pertanyaan yang ditanyakan oleh seorang siswa yang datang menghampiri peneliti pada saat peneliti memeriksa pekerjaan kelompok.

c. Pada saat melakukan pemeriksaan peneliti menghampiri satu demi satu kelompok untuk mengetahui kesulitan apa yang mereka hadapi. Sampailah peneliti pada salah satu kelompok, saat itu juga mereka langsung menanyakan: Siswa : bu bu pertanyaan nomor 2 ini kan berdasarkan gambar pada soal nomor 1 kan bu?

P :iya, lalu?

Siswa : nah bu, nentuke segitiga siku-siku apo bukannyo pake busur berdasarkan petunjuk yang ini? (sambil menjunjuk LKS)

$P \quad$ : iya, terus sulitnya dimana? Siswa : nah bu, bingung caro pake busurnyo hehe lupo

$P \quad$ : yang lain ada yang bisa?

Siswa : samo be bu, kami tu bingung sisi yang ini atau yang ini (sambil menunjuk busur)

$P \quad:$ coba sekarang letakkan busur menghadap atas pada angka 90 pada sudut yang terbentuk oleh sisi terpendek dan sisi terpanjang kedua.

Siswa : cak ini bu jadinyo, nas garisnyo pas di $90 \mathrm{bu}$

$P \quad$ : jadi? Coba baca lagi petunjuknya

Siswa : berarti segitiga siku-siku bu

$P \quad$ : nah itu mengerti, tidak sulit bukan menggunakan busur

Siswa : hehe kan lupo bu tadi

Dari percakapan peneliti dengan siswa dalam proses pembelajaran peneliti 
mengetahui bahwa siswa mengalami kesulitan ketika akan menentukan sudut apa yang terbentuk guna menentukan apakah gambar segitiga yang mereka buat termasuk dalam segitiga siku-siku, lancip atau tumpul. Kesulitan tersebut muncul karena kelompok ini lupa bagaimana cara menggunakan busur dengan baik. Terbukti setelah diajarkan mereka langsung mengerti. Dari percakapan tersebut pula peneliti mengetahui bahwa siswa mampu melakukan indikator aktivitas lisan, aktivitas mendengar, dan aktivitas metrik dan aktivitas emosional.

Selanjutnya peneliti melanjutkan pemeriksaan sampai pada kelompok terakhir. Pada saat peneliti sampai pada kelompok terakhir peneliti langsung ditanyai oleh siswa, salah satu siswa bertanya:

$\begin{array}{ll}\text { Siswa } & : \text { ibu-ibu } \\ P & : i y a\end{array}$

Siswa : ibu-ibu apakah $c^{2}$ itu selalu untuk sisi terpanjang, $a^{2}$ untuk sisi terpendek, dan $b^{2}$ untuk sisi yang satunya maksudnya sisi alas?

$P \quad$ : pada dasarnya tidak, biasanya bila ada soal maka dari soal tersebutlah yang menentukan. Misal suatu segitiga memiliki sisi $a=8 \mathrm{~cm}, b$ $=4 \mathrm{~cm}$ dan $\mathrm{c}=2 \mathrm{~cm}$.

Siswa : artinya dari soal yang ibu tadi untuk sisi terpanjangnya adalah $a^{2}$.

$P \quad:$ nah dengan demikian, tidak melulu sisi c yang menjadi sisi terpanjang atau sisi miring
Siswa : oohh begitu... ngerti bu ngerti.

Dari percakapan peneliti dengan siswa dalam proses pembelajaran peneliti mengetahui bahwa siswa telah memahami apa yang ia kerjakan, sehingga ia mampu memikirkan apakah nama sisi-sisi dari sebuah segitiga dalam teorema pythagoras selalu tetap atau berubah. Dari hasil percakapan tersebut pula peneliti mengetahui bahwa siswa mampu melakukan indikator aktivitas visual, aktivitas lisan, aktivitas mental, aktivitas mendengar, dan aktivitas emosional.

Dari gambar di atas dapat dilihat bahwa jawaban pada gambar atas adalah jawaban yang tepat dan jawaban pada gambar bawah adalah jawaban yang kurang tepat. Hal ini dikarenakan siswa kurang mampu mengumpulkan informasi yang sesuai dengan hipotesis yang telah dibuat sebelumnya, sehingga siswa kurang memahami apa yang diinginkan oleh soal. Namun, sampai pada tahap ini siswa telah mampu melakukan aktivitas mental dengan baik.

2. Deskripsi Hasil Pelaksanaan Penelitian

Data observasi yang diperoleh dari hasil pengamatan aktivitas siswa dari pertemuan kedua sampai pertemuan keempat, kemudian dicari nilai rata-rata observasi tiap pertemuan dan nilai ratarata seluruh pertemuan dan dikelompokkan berdasarkan kategori sangat aktif, aktif, cukup aktif, kurang aktif, dan sangat kurang aktif. 
Tabel 1.

Rata-rata Aktivitas Siswa Tiap Pertemuan

\begin{tabular}{|ccc|}
\hline Pertemuan & Rata-rata & Kategori \\
\hline Pertemuan Kedua & 63 & Cukup Aktif \\
\hline Pertemuan Ketiga & 78 & Aktif \\
\hline Pertemuan Keempat & 85 & Aktif \\
\hline Jumlah & 226 & \\
\hline Rata-rata & 75 & Aktif
\end{tabular}

Dari tabel di atas dapat diketahui bahwa pada pertemuan kedua rata-rata aktivitas siswa adalah 63 dengan kategori cukup aktif, hal ini menandakan bahwa rata-rata siswa mampu melakukan 3-4 indikator aktivitas belajar. Pada pertemuan ketiga dan keempat kativitas belajar siswa berada pada kategori aktif, artinya ratarata siswa mampu melakukan 5-6 indikator aktivitas belajar. Begitu pula dengan keseluruhan aktivitas dari tiga kali pertemuan berada pada kategori aktif dengan rata-rata 75 yang menandakan rata-rata siswa mampu melakukan 5-6 indikator aktivitas belajar.

Berdasarkan tabel di atas juga dapat diketahui bahwa kategori aktivitas siswa dari pertemuan kedua sampai pertemuan keempat mengalami peningkatan yang cukup pesat pada setiap pertemuannya, walaupun pada pertemuan pertemuan ketiga dan keempat berada pada kategori yang sama.

\section{B. Pembahasan}

Dari hasil penelitian ini dapat diketahui bahwasanya penelitian mengenai "Penerapan Metode Two Stay Two Stray (TS-TS) Untuk Melihat Aktivitas Siswa Pada Pembelajaran Matematika di SMP Negeri 19 Palembang" ini memiliki kategori aktivitas belajar aktif dan cukup aktif. Pada penelitian ini peneliti menggunakan indikator-indikator aktivitas belajar siswa. Berdasarkan hasil observasi, wawancara, dokumentasi serta dari temuan-temuan yang telah disebutkan. Hasil observasi pada pertemuan kedua berada pada kategori cukup aktif dengan rata-rata 63. Hal ini dikarenakan terdapat 10 siswa berada pada kategori sangat aktif, 6 siswa berada pada kategori aktif, 1 siswa berada pada kategori cukup aktif, 8 siswa berada pada kategori sangat kurang aktif, dan 6 siswa berada pada kategori sangat kurang aktif. Hal ini disebkan karena siswa masih beradabtasi dengan metode pembelajaran yang digunakan oleh peneliti, sehingga menyebabkan cukup banyak siswa yang belum mampu melakukan indikator aktivitas belajar.

Pada pertemuan ketiga hasil observasi berada pada kategori aktif dengan ratarata 78. Hal ini dikarenakan terdapat 16 siswa berada pada kategori sangat aktif, 5 siswa berada pada kategori aktif, 3 siswa berada pada kategori cukup aktif, 4 siswa berada pada kategori sangat kurang aktif, dan 2 siswa berada pada kategori sangat kurang aktif. Hal ini disebkan karena siswa telah memiliki pengalaman dengan metode pembelajaran yang digunakan oleh peneliti pada pertemuan kedua, sehingga menyebabkan cukup banyak siswa yang mampu melakukan indikator aktivitas belajar.

Pada pertemuan keempat hasil observasi berada pada kategori aktif dengan rata-rata 85 . Kategori ini sama 
dengan kategori aktivitas pada pertemuan ketiga, namun besaran rata-ratanya memiliki perbedaan yang cukup besar. Hal ini dikarenakan terdapat 23 siswa berada pada kategori sangat aktif, 3 siswa berada pada kategori aktif, 3 siswa berada pada kategori cukup aktif, 1 siswa berada pada kategori sangat kurang aktif, dan 1 siswa berada pada kategori sangat kurang aktif. Hal ini disebkan karena siswa telah mampu beradabtasi dengan metode pembelajaran yang digunakan oleh peneliti pada pertemuan kedua dan ketiga, sehingga menyebabkan cukup banyak siswa yang mampu melakukan indikator aktivitas belajar.

Dari hasil observasi selama tiga kali pertemuan diperoleh 12 orang siswa memiliki aktivitas belajar sangat aktif, 7 orang siswa memiliki aktivitas belajar aktif, 8 orang siswa memiliki aktivitas belajar cukup aktif, 3 orang siswa memiliki aktivitas belajar kurang aktif, dan 1 orang siswa memiliki aktivitas belajar sangat kurang aktif. Siswa dengan kategori aktivitas belajar sangat aktif rata-rata mampu melakukan deskriptor dari 7-8 indikator aktivitas belajar dalam setiap pertemuan. Siswa dengan kategori aktivitas belajar aktif rata-rata mampu melakukan deskriptor dari 7-8 indiktor aktivitas belajar, tetapi tidak dalam setiap pertemuan. Siswa dengan kategori aktivitas belajar cukup aktif rata-rata tidak mampu melakukan lebih dari 1 deskriptor dari masing-masing indikator dalam satu pertemuan. Siswa dengan kategori aktivitas belajar kurang aktif rata-rata tidak mampu melakukan lebih dari 1 deskriptor dari masing-masing indikator lebih dari satu pertemuan. Siswa dengan kategori aktivitas belajar sangat kurang aktif hanya mampu melakukan 1-2 deskriptor dari 7-8 indikator pada dua pertemuan. Sehingga dapat disimpulkan bahwa, semakin banyak deskriptor yang muncul dari masingmasing indikator aktivitas belajar, maka akan semakin aktif pula siswa dalam proses pembelajaran. Hal ini dikarenakan siswa menggali sendiri pengetahuannya bersama teman kelompok, dalam proses menggali pengetahuan tersebutlah siswa mampu melakukan deskriptor dari masingmasing indikator aktivitas belajar, sehingga proses pembelajaran akan terasa lebih bermakna bagi siswa. Hal ini sejalan dengan yang dikemukakan Herawati (2015) dalam penelitiannya yang mengatakan jika pengetahuan digali sendiri oleh peserta didik dan guru memfasilitasi kegiatan belajar peserta didik maka pembelajaran akan lebih bermakna. Dengan demikian, dapat disimpulkan bahwa semakin tinggi tingkat kemampuan siswa, maka akan semakin mudah pula siswa dalam proses pembelajaran. Artinya siswa tidak akan mengalami kesulitan yang berarti dalam melakukan deskriptor-deskriptor dari masing-masing indikator aktivitas belajar selama proses pembelajaran berlangsung. Hal ini sesuai dengan pendapat Dalyono (2007: 56) yang mengatakan bahwa seseorang yang memiliki tingkat kemampuan tinggi umumnya mudah belajar dan hasilnya pun cenderung baik. 
Sebaliknya orang yang kemampuannya rendah cenderung mengalami kesukaran dalam belajar, sehingga prestasi belajarnya pun rendah.

\section{Penutup}

Berdasarkan hasil penelitian yang telah diuraikan, maka diperoleh kesimpulan bahwa aktivitas belajar siswa setelah diterapkan metode Pembelajaran Two Stay Two Stray (TS-TS) pada proses pembelajaran matematika di SMP Negeri 19 Palembang berada pada kategori aktif dengan rata-rata 75, dimana ada 12 orang siswa dengan kategori aktivitas belajar sangat aktif, 7 orang siswa dengan kategori aktivitas belajar aktif, 8 orang siswa dengan kategori aktivitas belajar cukup aktif, 3 orang siswa dengan kategori aktivitas belajar kurang aktif, dan 1 orang siswa dengan kategori aktivitas belajar sangat kurang aktif. Kategori ini mengalami peningkatan pada setiap pertemuannya, terbukti dari rata-rata aktivitas siswa pada pertemuan kedua 63, rata-rata aktivitas siswa pertemuan ketiga 78, dan rata-rata aktivitas siswa pertemuan keempat 85.

Berdasarkan hasil penelitian dan keterbatasan peneliti, maka saran dari peneliti adalah sebagai berikut: (1) Dengan adanya penelitian ini, harapannya guru dan calon dapat mencoba menggunakan metode Two Stay Two Stray (TS-TS) untuk diterapkan pada pokok bahasan yang lain. Tujuannya supaya siswa mempunyai kesiapan, kedisiplinan, rasa tanggung jawab serta termotivasi dalam pembelajaran, sehingga dapat meningkatkan aktivitas dan hasil belajar matematika siswa; (2) Hendaknya peneliti yang akan datang harus lebih memperhatikan kembali deskriptor untuk tipa-tiap indikator dan peneliti juga dapat menambahkan teknik pengumpulan data dilapangan berupa angket guna mendapatkan hasil yang lebih valid lagi dalam menentukan kategori aktivitas belajar siswa. Selanjutnya peneliti juga bisa mengadakan penelitian lanjutan mengenai bagaimana cara meningkatkan aktivitas belajar siswa, dengan materi pembelajaran yang disesuaikan dengan metode pembelajaran yang mampu untuk meningkatkan aktivitas belajar siswa; (3) Hendaknya peneliti yang akan datang melakukan evaluasi terhadap hasil belajar guna menentukan tingkat kemampuan siswa, sehingga dapat dianalisis hubungan antara kategori aktivitas belajar dan kemampuan siswa; dan (4) Hendaknya peneliti yang akan datang melakukan penelitian lebih dari 4 kali pertemuan, guna mendapatkan hasil penelitian yang benar-benar maksimal hasilnya.

\section{Daftar Pustaka}

A.M, Sardiman. (2010). Interaksi dan Motivasi Belajar Mengajar. Jakarta: PT. Raja Grafindo Persada Dalyono, M. (2007). Psikologi Pendidikan. Jakarta: Rineka Cipta.

Dewi, Kurnia. (2014). Pengaruh Model Pembelajaran Kooperatif Tipe Two Stay Two Stray Terhadap Hasil Belajar Siswa Pada Mata Pelajaran 
Matematika Di Kelas X SMA Negeri 1 Gelumbang Muara Enim. Skripsi.

Palembang: Fakultas Tarbiyah dan Ilmu Keguruan IAIN Raden Fatah.

Herawati. (2015). Penerapan Model

Pembelajaran Two Stay Two Stray Untuk Meningkatkan Prestasi Belajar Siswa Pada Materi Keliling dan Luas Lingkaran di Kelas VI SD Negeri 53 Banda Acaeh. Jurnal Peluang, Vol.3, No.2, April 2015 tersedia di (http://jurnal.unsyiah.ac.id). Diakses 08 Februari 217.

Hamalik, Oemar. (2004). Proses Belajar Mengajar. Bandung: Rosda.

Oviyanti, Fitri. (2009). Pengelolaan Pengajaran. Palembang: Rafah Press. Redaksi Sinar Grafika. (2011). UndangUndang SISDIKNAS (Sistem Pendidikan
Nasional UU RI no. 20 Tahun 2003). Jakarta: Sinar Grafika.

Saputra, Very Hendra. (2015). Eksperimentasi Model Pembelajaran Kooperatif Tipe Two Stay Two Stray Dengan Pendekatan Matematika Realistik Pada Materi Bangun Ruang Sisi Datar Ditinjau Dari Aktivitas Belajar Siswa Smp Kelas Viii Di Kabupaten Sleman Tahun Pelajaran 2013/2014. Jurnal Elektronik Pembelajaran Matematika, Vol.3, No.2, hal 156-166, April 2015 tersedia di(http://jurnal.fkip.uns.ac.id) diakses 15 Desember 2015.

Zaini, Hisyam. (2011). Pembelajaran Aktif. Jakarta: CTSD 